\title{
Project Based Learning Improves 5-6 Years Olds Cooperative Skills
}

\author{
Melia Dwi Widayanti \\ Graduate School, \\ Universitas Negeri Yogyakarta \\ Yogyakarta, Indonesia \\ melia.dwi2016@student.uny.ac.id
}

\author{
Farida Agus Setiawati \\ Graduate School \\ Universitas Negeri Yogyakarta \\ Yogyakarta, Indonesia \\ farida_as@uny.ac.id
}

\begin{abstract}
All of educational process referring to $21^{\text {st }}$ century educational purpose, and having a cooperative skill is one of them. This has increased the need of learning method that could improve children's cooperative skills. In this research, we implement project-based learning on 44 children (5-6 years old) of Al-Hikmah Kindergarten learning process to improve their cooperative skills. This experiment uses nonequivalent control group design and divided into three phases, which are pretest, treatment, and posttest that happened for 5 weeks. Observation sheets used for measuring children's cooperative skills. Analysis data technique that used are quantitative. Comparison between children's cooperative skills before and after implementation done by paired sample t-test using SPSS 16.0 for Windows. The result of paired sample t-test shows that there is a significant improve on children's cooperative skills by using project-based learning. Based on the data, we conclude that project-based learning could improve children's cooperative skills.
\end{abstract}

Keywords-cooperation, kindergarten, project-based learning, children

\section{INTRODUCTION}

In this $21^{\text {st }}$ century, we came into globalization era. Process of economic, social, political, cultural, and territorial integration according to the world system theory is what globalization meant [1]. Globalization giving an impact to a lot of aspect, and education is one of them. Because of globalization, the educational aim has shifted. Core skills, soft skills, generic skills, transferable knowledge, key skills, college and career readiness, student centered learning, new basic skills, and twenty-first century skills are the terms that has been encountered by some literatures [2][5]. These terms mostly cover work-related, social and personal competencies, cognitive and non-cognitive ones, such as critical thinking, problem solving, cooperation, effective communication, motivation, persistence, learning to learn, IT literacy, social and emotional skills, and at times also creativity, innovation and ethnics [6].

Social competencies are one of competencies that children should have. Children develop their social competencies when they are playing. When children have a good relationship with others, they will experience a happy life and gain a lot of experience from social interaction that happened between them.

Social interactions among children can play a significant role in their development, both short-term and long-term [7]. Interaction between children with adult or other children have crucial role in the development of more sophisticated physiological functions. When children interact with others, it will provide a various opportunity to learn, practice, and develop their communicative, interactive, and cooperation skills.

Cooperative skills are important to face global competition and one of international educational purpose [8][9]. Such cooperative skills develop early in life as toddlers and preschoolers gain perspective-taking abilities and come to understand the behaviors of others in terms of mental states [10][11]. If children have a good cooperative skill, they will have a good sensitivity and could build a good relationship with others.

Cooperative skills give an effect to children's cognitive skill. When children interact with each other and seek information, they generally attract five times as many information exchanges for each request, hence increasing the possibility that group members will exchange more relevant information [7]. On cooperation, there is approaching process and working together based on one purpose that need the work of everyone [12]-[14] When we give children a chance to cooperate, they know they each contribute to the success of the venture. Each child realize they plays a vital role in the outcome and accept a responsibility in fulfilling that role [15].

However, based on preliminary observation in AlHikmah Kindergarten found that cooperative skills of 56 years old children there are low. In a learning process, some children still cannot share the work equally. The same problem also found in Kristen Maranantha Kindergarten [16]. However, preschool children tend to be easy, relented, cooperative, especially when they are playing [17]. Because of that, there should be a correct way to improve children's cooperative skills.

Further interviews with teachers in Al-Hikmah Kindergarten indicate that teacher doesn't really pay 
attention to children's cooperative skills. In learning process, they only focus on improving children's cognitive, language, and motoric skills. The usage of learning method variation doesn't really happen because they tend to use a learning method that doesn't really have a lot of preparation, such as paper-based task.

Project Based Learning (PBL) is known for its ability to connecting children with a real-world learning. It makes school more engaging and meaningful. Project based learning builds on individual strengths and allows individual to explore [18]. A new challenges and new roles in the learning process will be faced by teacher if they apply PBL. The student roles include autonomy and responsibility on what they learn, how they learn and with whom [19]. PBL provides a set of activities related to management and planning processes that only seems possible in teams [20]. Students must organize themselves in a team, manage a project, make decisions and find solutions [19]. An intense and extended interaction between team members is something that related to project-based learning.

PBL is one of the best ways to build skills such as critical thinking, collaboration, and communication [21]. PBL appears to be an equivalent or slightly better method for producing gains in academic achievement [22]. In Indonesia, PBL rarely used as a learning method in kindergarten, even though children get a lot of beneficial from it. By using PBL on class, preschool students in Turkey enjoyed the project work and noted improved self-confidence, creativity, ability to plan and develop ideas, problem-solving skills, and the benefits of working in groups [23]. The result of study in Greece also conclude that preschool student can develop groupwork skills in addition to motivation and positive attitudes towards peers from a different ethnic background through PBL [24].

To solve the lack of children's cooperative skills in Al-Hikmah Kindergarten, this paper presents an experiment of project-based learning in preschool student. More particularly, we use project-based learning to improve 5-6 years old children cooperative skills.

The organization of this paper is as follows: Related work presented in Sect. 2; description of proposed methodology is given in Sect.3. For the Result, given in Sect.4, and the Conclusion given in Sect.5.

\section{LITERATURE REVIEW}

In order to address this issue and make a sequence about literature review that already exist, we divide it into children's cooperative skills and project-based learning. Existing literature to improving children's cooperative skills using project-based learning are as follows.

\section{A. Children's Cooperative Skills}

As we know, human are social creatures. They always keep in touch and need other people in their life. Children's surrounding will provide children's interaction naturally. Interaction between their social could not be separated from their daily life such as social relationship with family, school, and many more. In order to have a good relationship with their social, children should have a good social skill. The ability to do twoways communication, cooperate with others, and empathy is something that could make a good relation happen [25].

The capacity to cooperate with others is a unique skill for human, especially children. Approaching process happens to unite the thoughts of each member to achieve common goals. The goal is to fulfil demand of a situation [26]. When children create their team goals, children feel responsible for their join commitments and they will try to honor them [27]. In cooperative, there is also an interaction, responsibility, and personal dependences.

Although cooperation involves more than one person, it is different from working together on the same place. When children working together, they might work on the same place but there are no dependencies among them. While in cooperation, they are working closely together (or far apart), even though they do a different thing, they do it in order to achieve the same goal that needs the work of each other [14]. Cooperative activities will give wider advantages and achieved goals for children compare to working independently.

Every children's cooperative skills might be different. It depends on some factors, internal and or external. Cooperative skill begins to appear in 18 months of their life [28]. Preschool age (3-7 years) is when children's cooperative skills develop faster. In their third and fourth year, they begin to show their cooperative skills with others. And it starts becoming better when they are six or seven, when they start to work cooperatively with others.

Cooperative skills in a group will not be longer if there is no loyalty in the group [29]. Children's shyness will also give an impact to their cooperative skills, because children tend to withdrawal from others [30]. When it comes to family context, the positive relationship between parents and children will give its impact to children cooperative skills. Research shown that youngest children has better skills compare to oldest in terms of cooperative skills [31]. Cooperative contain of eight characteristics, which are positive dependent, interaction, responsibility, sharing, negotiation, and perspective taking [8][32]. 


\section{B. Project Based Learning}

Project based learning is a new version of project method that Kilpatrick created [33]. The change of project method from Thorndike's psychology of learning informing to constructivist learning have led by advances in educational psychology on how children learn from Piaget, Vygotsky, and Bruner, as well as more recent research on learning theory, including multiple intelligences [34], theories of intelligences [35], and learning communities [36].

Project based learning in kindergarten served as a learning method, but if in Junior High School, Senior High School, and college project serves as a systematic instruction [37]. In this learning, real-world problem is the essential key to lead a project. Real world problem lead children to meaningful learning experiences [38].

Basically, every activity in every educational level can be a project if children get an experience and it has a clear purpose [39]. But, more specific, there are four essential characteristics of projects [40]: (1) centrality (2) driving question (3) constructive investigations and (4) realism: projects are realistic, not school-like. Projects embody characteristics that give them a feeling of authenticity to students PBL needs children collaboration, reflection, redrafting and presentations emphasized in other publications [41]. There are six steps in PBL, which are: (1) Essential Question, (2) Plan, (3) Schedule, (4) Monitor the Progress, (5) Asses the Outcome and (6) Evaluate the Experience [18].

There are a lot of benefits that children can get from project-based learning. The steps of PBL is the organization of teaching and educational activity during which its participants acquire knowledge in the course of planning and performance of practical problems-projects [42].

\section{METHODOLOGY}

A lot of work done in the area of cooperation skills and project-based learning. In this work, we implement project-based learning in 5-6 years old children in order to improve their children's cooperative skills.

\section{A. Data}

A subset of participants was students in Al-Hikmah Kindergarten that located in Yogyakarta, Indonesia. We implement project-based learning to 44 children, which divided into B1 and B2. B1 contain of 11 boys and 11 girls, and B2 contain of 11 boys and 11 girls. The data of children's cooperative skills recorded by cooperative skills observation sheets. Previously, cooperative skills observation sheets created and assessed by experts.
TABLE I. COOPERATIVE SKILLS OBSERVATION SHEETS

\begin{tabular}{|c|c|c|}
\hline \multicolumn{3}{|c|}{ GUIDELINE } \\
\hline No & Aspects & Criteria \\
\hline \multirow{3}{*}{1.} & \multirow{3}{*}{$\begin{array}{l}\text { Positive } \\
\text { dependences }\end{array}$} & a. Give a contribution on group \\
\hline & & b. Give support to others \\
\hline & & c. Give a help to friend or teacher \\
\hline \multirow{2}{*}{2.} & \multirow{2}{*}{$\begin{array}{l}\text { Personal } \\
\text { responsibility }\end{array}$} & a. Keep their goods well \\
\hline & & b. Obey the rules \\
\hline \multirow{2}{*}{3.} & \multirow{2}{*}{ Interaction } & $\begin{array}{l}\text { a. Have a good relationship with } \\
\text { friend and teacher }\end{array}$ \\
\hline & & $\begin{array}{l}\text { b. Do a communication with friend } \\
\text { and teacher }\end{array}$ \\
\hline
\end{tabular}

After all the data collected, we did analysis of children's cooperative skills. We did it by using comparison on children's cooperative skills score and paired sample t-test. It done by using SPSS for Windows. If level of significance lower than 0,05, Ha accepted; but if the level of significance higher than 0,05 , then Ho accepted.

Ho: There is no significant improve on children's cooperative skills

Ha: There is a significant improve on children's cooperative skills

\section{B. Method}

In this section, we would explain three steps how we done the research. These steps are:

\section{- Pretest}

Pretest intended to know children's cooperative skills before the treatment given. It happens for 1 weeks and done by 6 observants excluded teachers. Children's cooperative skills assessed since the learning process started until it ends by using cooperative skills observation sheet.

\section{- Implementation}

Implementation started after the data collected. The group contains of 22 boys and 22 girls. They located in two rooms, B1 and B2. Each room composed by 11 boys and 11 girls with two teachers. Before the implementation started, we gave an instruction for teacher on how this implementation work. One observant stayed in each room to observe did teacher does the plan well.

The project that implemented in this study is about bees. Children asked to make a project about bees, and they presented it in front of class. They worked in a group with 3-5 children. Implementation held every day in two weeks.

\section{- Posttest}

After we done with implementation process, posttest happened. Posttest intended to know children's cooperative skills after the treatment given. It happened for 1 weeks and done by 6 observants. Children's 
cooperative skills assessed by cooperative skills observation sheet.

\section{THE DATASET}

This section presents result and discussion of this research.

\section{A. The Result of Children Cooperative Skills}

Besides doing hypothesis test, we also compare children's cooperative skills score directly. We compare children's score before implementation and after implementation. The data was collected by using cooperative skills observation sheets before and after implementation happened. The result of children's cooperative skills score is:

TABLE II. COMPARATION OF CHILDREN'S
COOPERATIVE SKILLS BEFORE AND AFTER
IMPLEMENTATION
\begin{tabular}{|c|c|}
\hline \multicolumn{2}{|c|}{ Score } \\
\hline Pretest & Posttest \\
\hline $43,37 \%$ & $59,32 \%$ \\
\hline
\end{tabular}

Based on Table 2, the difference of children's cooperative skills before and after implementation can be seen. There in an enhancement of children's cooperative skill score after project-based learning implemented as much as $15,59 \%$. Based on the finding, we conclude that project-based learning can improve children cooperative skills.

\section{B. Prerequisite Test}

Before we do the paired sample t-test, we should make sure that data are normal and homogeny. For the normality test, we use Shapiro-Wilk test from SPSS for Windows. If the significance level is higher than 0,05 than we can conclude that the data are normal.

\begin{tabular}{|c|c|}
\hline Test & Significance Level \\
\hline Pretest & .283 \\
\hline Post test & .698 \\
\hline
\end{tabular}

As seen on Table 3, the data from each group has higher significance level than 0,05. Based on that, we can conclude that all the data are has normal distribution.

Homogeneity test done to know whether the data come from homogeny population or not. We use Levene Statistic from SPSS to test the data. If the significance level is higher than 0,05 than we can conclude that the data are homogeny.

TABLE IV. TEST OF HOMOGENITY OF VARIANCES

\begin{tabular}{|l|l|}
\hline Levene Statistics & Significance Level \\
\hline .250 & .618 \\
\hline
\end{tabular}

As seen on Table 4, the data has higher significance level than 0,05. Based on that, we can conclude that all the data are homogeny. After the normality and homogeneity of the data proven, hypothesis test happened.

\section{Paired Sample t-test}

For paired sample t-test, it calculated by using SPSS for Windows. And the result is.

TABLE V. INDEPENDENT SAMPLE TEST

\begin{tabular}{|l|c|}
\hline Pair & Sig \\
\hline Pretest - Post & .000 \\
\hline
\end{tabular}

As seen on Table 4, significance level of group is 0.000 and it is lower than 0,05; Ha accepted. on that result, we can conclude that a significant improve on children's cooperative skills happened.

\section{CONCLUSION}

In this paper, usage of project-based learning to improve children's cooperative skills has been proposed. From the result of paired sample t-test we can conclude that there is a significant improve on children's cooperative skills by using project-based learning. Our future work will focus on the impact of other skills that could improve by using project-based learning.

\section{REFERENCES}

[1] Arrighi, G. Hegemony unravelling. New Left Review, 32, 2005.

[2] Barrie, S. C. Understanding what we mean by the generic attributes of graduates. Higher education, 51(2), 2006, pp. 215241.

[3] Boud, D., Garrick, J., \& Greenfield, K. Understanding learning at work. Performance Improvement, 39(10), 2000, pp. 45-47.

[4] Bridges, D. Transferable skills: a philosophical perspective. Studies in Higher Education, 18(1), 2006, pp. 43-51.

[5] Pellegrino, James \& Hilton, Chair Margaret. Education for life and work: Developing transferable knowledge and skills in the 21st century. National Academies Press, 2013.

[6] Pesikan, Ana \& Lalovic, Zoran. Education for life: Key $21^{\text {st }}$ century competencies in curricula in montenegro. Podrogica, 2017.

[7] Bales, R.F. Personality and interpersonal behaviour. New York: Holt, Richart \& Winston, 1970.

[8] Molenda, Catherine F. \& Bhavnagri, Navaz Peshotan. Cooperation through movement education and children's literature. Early Childhood Educ J 37, 2009, pp. 153-159.

[9] Piaget, Jean. The spirit of solidarity in children and international cooperation. Schools: Studies in Education. Spring 2011, Vol 8 Isuиe 1, 1931, pp. 74-89.

[10] Tomasello, M., \& Hamann, K. Collaboration in young children. The Quarterly Journal of Experimental Psychology, 65(1), 1, 2012.

[11] Warneken, F., \& Tomasello, M. Altruistic helping in human infants and young chimpanzees. Sciense, 311, 2006, pp. 13011303. 
[12] Yudha, Saputra M. \& Rudyanto. Pembelajaran kooperatif untuk meningkatkan keterampilan anak TK. Jakarta: Departemen Pendidikan Nasional, 2005.

[13] Freedman, Jonathan L. \& Sears, David O. Social Psychology, 1985.

[14] Vasiloff, Barbara C., Teaching self-discipline to children. USA: Twenty- Third Publications, 2003.

[15] Pica, Rae. Helping children cooperate. Young children, 2011, pp. 60-61

[16] Mering, A., \& Ali, M. Peningkatan kerjasama anak dalam bermain melalui metode kerja kelompok. Jurnal Pendidikan dan Pembelajaran, 4(6), 2015

[17] Geldard, Kathryn. Counselling Children: A Practical Introduction. Sage Publications, 2013.

[18] Yussof, D. H. B. H. Project based learning handbook "Educating the millenial learner". Educational Technology Division, Ministry of Education, 2006.

[19] Alves, A. C., Mesquita, D., Moreira, F., \& Fernandes, S. Teamwork in project-based learning: Engineering students' perceptions of strengths and weaknesses. In Proceedings of the Fourth International Symposium on Project Approaches in Engineering Education (PAEE'2012), 2012 pp. 23-32.

[20] Cinar, Y., \& Bilgin, A. Peer assessment for undergraduate teamwork projects in petroleum engineering. International Journal of Engineering Education, Vol. 27, Issue 2, 2011, pp. 310-322.

[21] Mergendoller, John R, Larmer, John, \& Hallerman, Sara. PBL in the elementary grades. California: Buck Institute for Education, 2011.

[22] Buck Institute for Education. Introduction to Project Based Learning, 2010. Taken on 15 November 2017, from htttp://bie.org.images/

[23] Holm, M. PROJECT-BASED INSTRUCTION: A Review of the Literature on Effectiveness in Prekindergarten. River academic journal, 7(2), 2011, pp. 1-13.

[24] Kaldi, S., Filippatou, D., \& Govaris, C. Project-based learning in primary schools: Effects on pupils' learning and attitudes. Education 3-13: International Journal of Primary, Elementary and Early Years Education, 39, 2011, pp. 35-47

[25] Izzaty, R. E., Setiawati, F. A., \& Ayriza, Y. Pengembangan buku panduan program pembelajaran keterampilan sosial bagi guru taman kanak-kanak. Jurnal Penelitian Ilmu Pendidikan, 10(1), 2017, pp. 30-39.

[26] Deutch, J. A. The Respectful Parent: A Manual for Moms and Dads. Xlibris Corporation, 2012.

[27] Tomasello, M., \& Vaish, A. Origins of human cooperation and morality. Annual Review of Psychology, 64, 2013, pp. 231-255.

[28] Walker, L. M., \& Carlo, G. (Eds.). Prosocial development: A multidimensional approach. Oxford University Press, 2015.

[29] Mangal, S. K., \& MANGAL, S. Emotional intelligence: Managing emotions to win in life. PHI Learning Pvt. Ltd, 2015.

[30] Eggum-Wilkens, N. D., Valiente, C., Swanson, J., \& LemeryChalfant, K. Children's shyness, popularity, school liking, cooperative participation, and internalizing problems in the early school years. Early Childhood Research Quarterly, 29(1), 2014, pp. 85-94.

[31] Prime, H., Plamondon, A., \& Jenkins, J. M. Birth order and preschool children's cooperative abilities: A within-family analysis. British Journal of Developmental Psychology, 35(3), 2017, pp. 392-405.

[32] Suyanto, Slamet. Dasar-dasar pendidikan anak usia dini. Yogyakarta: Hikayat Publishing, 2005.
[33] Pecore, J. L. From Kilpatrick's project method to project-based learning. International Handbook of Progressive Education, 2015, pp. 155-171.

[34] Howard, G. Frames of mind: The theory of multiple intelligences. NY: Basics, 1983.

[35] Sternberg, R. J., \& Sternberg, R. J. Beyond IQ: A triarchic theory of human intelligence. CUP Archive, 1985.

[36] Lave, J., Wenger, E., \& Wenger, E. Situated learning: Legitimate peripheral participation (Vol. 521423740). Cambridge: Cambridge university press, 1991.

[37] Phillips, D. C. Theory and philosophy. America: Sage Publications, Inc., 2014

[38] Kokotsaki, D., Menzies, V., \& Wiggins, A. Project-based learning: A review of the literature. Improving schools, 19(3), 2016, pp. 267-277.

[39] del Mar del Pozo Andrés, M. The transnational and national dimensions of pedagogical ideas: the case of the project method, 1918-1939. Paedagogica historica, 45(4-5), 2009, pp. 561-584.

[40] Thomas, J.W. A review of research on project-based learning. California: The Autodesk Foundation, 2000

[41] Kwon, S. M., Wardrip, P. S., \& Gomez, L. M. Co-design of interdisciplinary projects as a mechanism for school capacity growth. Improving Schools, 17, 2014, pp. 54-71

[42] Dudnyk, Nadiya. Usage of Project Method in Preschool Education. Vol. XXIX, 2, 2016.

[43] Pellegrini, A. D. The role of play in human development. USA: Oxford University Press, 2009. 
